\title{
FOENICULUM VULGARE MILLER COMO HOSPEDERA DE PULGONES Y SUS ENEMIGOS NATURALES EN OTOÑO
}

\author{
Lopez, O. ${ }^{1}$; SALTO, C. ${ }^{2} \&$ LUISELLI, S. ${ }^{2}$
}

\begin{abstract}
RESUMEN
La presencia de vegetación nativa puede mejorar el control natural de plagas, al proveer alimentación y hábitats a sus depredadores y parásitos. El objetivo del trabajo fue determinar, mediante muestreos en condiciones de campo durante otoño, la importancia de Foeniculum vulgare Miller como hospedante alternativa de pulgones y de sus enemigos naturales.

Los pulgones localizados fueron Hyadaphis foeniculi (1184 áfidos/planta), Dysaphis apiifolia, Aphis fabae y Cavariella aegopodii. Los depredadores encontrados incluyeron coccinélidos (Coccinella ancoralis, Cycloneda sanguinea y Eriopis connexa), sírfidos (Allograpta exotica) y crisópidos (Chrysopa sp.). El parasitoide presente fue el microhimenóptero Aphidius colemani.

Se encontraron altas correlaciones entre el total de pulgones y los huevos de depredadores, así como con el total de éstos, por lo que $C$. ancoralis, $C$. sanguinea, A. exotica y E. connexa tuvieron una respuesta numérica reproductiva a la presencia de $H$. foeniculi y A. fabae. Cycloneda sanguinea y E. connexa presentaron respuesta numérica agregativa con $H$. foeniculi.
\end{abstract}

Palabras clave: Foeniculum vulgare, control natural, áfidos, Coccinellidae, respuesta numérica.

\section{SUMMARY}

\section{Foeniculum vulgare Miller as autum host of aphids and its natural enemies.}

The natural vegetation can increase the pests natural control by provideing food and shelter to the entomophagous insects. The objetive of this work was to stablish the importance of Foeniculum vulgare Miller as host of aphids and its natural enemies.

The aphids found were Hyadaphis foeniculi (1184 aphids/plant), Dysaphis apiifolia, Aphis fabae and Cavariella aegopodii. The predators found were Coccinellidae (Coccinella ancoralis, Cycloneda sanguinea and Eriopis connexa); Sirphidae (Allograpta exotica) and Chrysopidae (Chrysopa sp.). The parasitoid found was the Hymenoptera Aphidius colemani.

High correlations were found among the total aphids and the predators eggs and the total of predators. Coccinella ancoralis, C. sanguinea, A. exotica and E. connexa have reproductive numerical response to the aphids $H$. foeniculi and A. fabae. Cycloneda sanguinea and E. connexa had aggregative numerical response to the aphid $H$. foeniculi.

Key words: Foeniculum vulgare, natural control, aphids, Coccinellidae, numerical response.

1.- Estudiante. Facultad de Ciencias Exactas, Físicas y Naturales. Universidad Nacional de Córdoba 2.- INTA, EEA Rafaela, C.C. 22. (2300) Rafaela, provincia de Santa Fe.

Manuscrito recibido el 7 de junio de 2002 y aceptado para su publicación el 3 de diciembre de 2003. 